\title{
ANALISIS UKURAN AGREGAT KASAR PADA SIFAT MEKANIS BETON
}

\author{
Abdul Hakim \\ Prodi Teknik Lingkungan, Universitas Islam Negeri Sunan Ampel, Jl. Jenderal A. Yani 117 Surabaya, Email: \\ abdulhakim.hakim48@gmail.com
}

\begin{abstract}
ABSTRAK
Beton yang baik adalah beton yang mempunyai sifat-sifat yang baik, yaitu beton memiliki kuat tekan yang baik, mudah dalam pengerjaannya, berdurabilitas dan ekonomis yaitu penggunaan material yang tepat dan ukuran yang sesuai. Dari sifat-sifat beton di atas salah satu yang mempengaruhi adalah ukuran agregat kasar. Maksud ukuran agregat kasar di sini tidak hanya pada besar diameter agregat tetapi juga gradasi dari agregat tesebut, oleh karena itu penelitian ini untuk menguji dari pengaruh tersebut. Penelitian ini dilakukan dengan eksperimen di Laboratorium dengan pembuatan benda uji silinder beton. Target kuat tekan beton pada umur 28 (dua puluh delapan) hari adalah $20 \mathrm{MPa}$ dan $40 \mathrm{MPa}$. Selain itu diuji pada besaran mekanis lainnya seperti Kekuatan tarik, modulus kelenturan dan modulus elastisitas sehingga berdasarkan hasil pengujian beton yang dilakukan di Laboratorium ini akan diperoleh hubungan diameter agregat terhadap sifat-sifat beton. Hasil penelitian ini diperoleh bahwa beton dengan menggunakan campuran agregat ukuran diameter $40 \mathrm{~mm}$ memeliki kuat tekan yang lebih besar hingga $5 \%$ dari kuat tekan beton dengan diameter agregat $20 \mathrm{~mm}$, demikian pula pada besaran mekanik lainnya yang menunjukkan bahwa beton dengan agregat diameter maksimum $40 \mathrm{~mm}$ lebih besar daripada beton dengan ukuran agregat maksimum $20 \mathrm{~mm}$.
\end{abstract}

Kata Kunci: ukuran agregat, sifat-sifat beton, biaya

\section{PENDAHULUAN}

Beton merupakan salah satu bagian konstruksi yang penting dalam bangunan infrastuktur baik di perkotaan maupun di pedesaan seperti : Bangunan gedung, perumahan, jalan raya, drainase, saluran irigasi, jembatan, bendungan, saluran pengelak dan bangunan pelimpah (spillway) pada waduk dan bangunan-bangunan lainnya.

Beton merupakan salah satu material yang paling banyak digunakan dalam dunia konstruksi. Di Indonesia, hampir $60 \%$ meterial yang digunakan dalam pekerjaan konstruksi adalah beton (concrete), yang pada umumnya dipadu dengan baja (composite) atau jenis lainnya (Mulyono, 2004: 135). Perpaduan ini biasa disebut sebagai beton bertulang. Berbeda dengan baja yang harus dibuat di pabrik, pembuatan beton untuk keperluan praktis misalnya rumah tinggal tidak memerlukan sumber daya berkeahlian khusus dalam pembuatannya. Hal ini membuat material beton semakin populer dan semakin banyak digunakan dalam dunia konstruksi.

Beton banyak digunakan karena sifat-sifatnya yang baik seperti pengerjaan yang mudah, memiliki kuat tekan sesuai yang diperlukan sehingga mampu memikul beban yang berat, tahan terhadap temperatur yang tinggi dan dibentuk dari material-material lokal yang mudah didapat.

Beton mempunyai jenis yang bermacam-macam sesuai dengan tingkat kualitasnya, beton mutu normal menurut SNI-2002, yaitu beton yang mempunyai kuat tekan antara 21- $41 \mathrm{MPa}$, Sedangkan kriteria beton mutu tinggi selalu berubah sesuai dengan kemajuan tingkat mutu yang berhasil dicapai. Pada tahun 1950-an, beton dengan kuat tekan $30 \mathrm{MPa}$ sudah dikategorikan sebagai beton mutu tinggi. Pada tahun 1960an hingga awal 1970-an, kriterianya lebih lazim menjadi $41 \mathrm{MPa}$. Saat ini, disebut mutu tinggi untuk kuat tekan diatas $50 \mathrm{MPa}$, dan diatas $80 \mathrm{MPa}$ sebagai beton mutu sangat tinggi, sedangkan untuk diatas $120 \mathrm{MPa}$ bisa dikategorikan sebagai beton bermutu ultra tinggi (Supartono, 1998). ACI Committae 2002 tentang High Strength Concrete merevisi definisinya menjadi memperoleh campuran dengan kuat tekan desain spesifikasi $55 \mathrm{MPa}$ atau lebih..

Campuran beton yang baik adalah beton yang mempunyai sifat-sifat yang baik, yaitu beton memiliki kuat tekan terhadap beban yang sudah direncanakan pada saat umur beton telah mencapai umur 28 hari, mudah dalam pengerjaannya yaitu dalam proses pengangkutan dan pada saat penuangan di lokasi pengecoran, berdurabilitas 
yaitu beton memiliki umur yang panjang atau tahan lama dan ekonomis yaitu penggunaan material yang tepat dan ukuran yang sesuai.

Dari sifat-sifat beton di atas salah satu yang mempengaruhi adalah ukuran agregat. Maksud ukuran agregat di sini tidak hanya pada besar diameter agregat tetapi juga gradasi dari agregat tesebut, oleh karena itu penelitian tesis ini untuk menguji dari pengaruh tersebut.

\section{METODE PENELITIAN}

Penelitian ini dilakukan dengan eksperimen di Laboratorium Teknologi Bahan Konstruksi Universitas Islam Sultan Agung Semarang . Dengan pembuatan benda uji silinder, beton ditarget mencapai kuat tekan mutu normal $20 \mathrm{MPa}$ dan $40 \mathrm{MPa}$.

\section{Bahan atau materi penelitian}

Bahan-bahan yang digunakan untuk membuat beton yang akan diuji adalah: Semen tipe I merek Semen Gresik, Pasir dari Muntilan, Split ukuran maksimal $20 \mathrm{~mm}$, dan $40 \mathrm{~mm}$, Air, Mix design yang digunakan untuk beton mutu normal dan beton mutu tinggi adalah metode ACI.

\section{Alat penelitian}

Dalam penelitian ini alat yang akan digunakan antara lain: Portable Mixer, centong, timbangan, scope, ember, mould dan perlengkapannya, alat tes slump, meteran, termometer.

\section{Langkah penelitian}

Langkah-langkah pelaksanaan penelitian ini terangkum dalam bagan alir sebagai berikut:

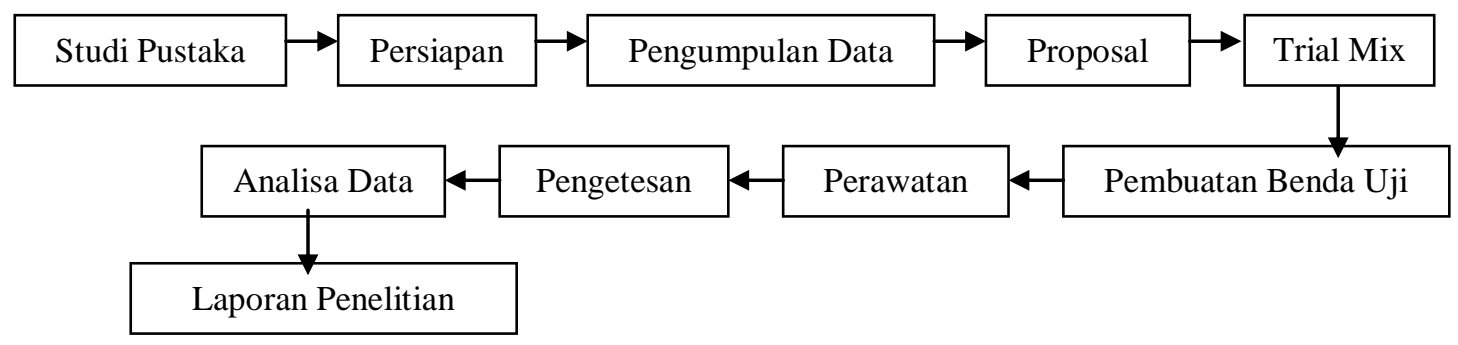

Gambar 1. Langkah Pelaksanaan Penelitian

\section{Variabel Data}

Data dalam penelitian ini berupa kumpulan sampel beton dengan keterangan sebagai berikut:

a. Sampel berupa silinder dengan diameter $15 \mathrm{~cm}$ dan tinggi $30 \mathrm{~cm}$

b. Tes Kuat tekan dan kuat lentur beton: 7 hari, 14 hari, dan 28 hari

c. Tes Kekuatan tarik sampel beton pada umur 28 hari

d. Tes Modulus kelenturan pada umur 28 hari

e. Tes Modulus Elastisitas pada umur 28 hari

f. Jumlah sampel 72 benda uji dengan keterangan sebagai berikut: 
Tabel 1 Jumlah benda uji beton

\begin{tabular}{|c|c|c|c|c|c|}
\hline \multirow{2}{*}{ No } & \multirow{2}{*}{ Mutu Beton } & \multicolumn{4}{|c|}{ Waktu Tes Kuat Tekan dan lentur } \\
\hline & & $7 \mathrm{hr}$ & $14 \mathrm{hr}$ & $28 \mathrm{hr}$ & Jumlah \\
\hline \multirow[t]{4}{*}{1} & Beton Mutu Normal & & & & \\
\hline & Ukuran maksimal 19 & 6 & 6 & 6 & 18 \\
\hline & Ukuran maksimal 40 & 6 & 6 & 6 & 18 \\
\hline & & & \multicolumn{2}{|c|}{ Komulatif } & 36 \\
\hline \multirow[t]{5}{*}{2} & Beton Mutu Tinggi & & & & \\
\hline & Ukuran maksimal 12 & 6 & 6 & 6 & 18 \\
\hline & Ukuran maksimal 19 & 6 & 6 & 6 & 18 \\
\hline & & & \multicolumn{2}{|c|}{ Komulatif } & 36 \\
\hline & & & \multicolumn{2}{|c|}{$\begin{array}{l}\text { Total benda } \\
\text { uji }\end{array}$} & 72 \\
\hline
\end{tabular}

\begin{tabular}{clc}
\hline No & \multicolumn{1}{c}{ Jenis Tes Mekanik } & Jumlah sampel \\
\hline 1 & Tes Kekuatan tarik & 6 silinder \\
\hline 2 & Tes Modulus Elastisitas & 6 silinder \\
\hline 3 & Tes Kekuatan lentur & 6 balok \\
\hline
\end{tabular}

\section{Metode analisis hasil}

Berdasarkan hasil pengujian beton yang dilakukan di Laboratorium akan diperoleh hubungan besar diameter agregat terhadap sifat-sifat beton.

\section{HASIL DAN PEMBAHASAN}

Tes material seperti dilakukan sebelum menentukan proporsi mix beton. Dalam menentukan proporsi mix beton menggunakan metode American Concrete Institu (ACI) dengan hasil seperti di bawah ini:

Tabel 5. Tabel proporsi mix campuran sampel beton

\begin{tabular}{cccccccccc}
\hline $\begin{array}{c}\text { Kuat } \\
\text { Tekan }\end{array}$ & $\begin{array}{c}\text { Uk. Max. } \\
\text { Agregat }\end{array}$ & Slump & $\begin{array}{c}\text { Kadar } \\
\text { udara }\end{array}$ & FAS & P/A & Air & Semen & Pasir & Split \\
\hline MPa & $(\mathbf{m m})$ & $(\mathbf{c m})$ & $\mathbf{\%}$ & & $\boldsymbol{\%}$ & $\mathbf{( k g )}$ & $\mathbf{( k g )}$ & $\mathbf{( k g )}$ & $\mathbf{( k g )}$ \\
\hline 20 & 20 & $10 \pm 2$ & 2,5 & 0,54 & 62 & 195 & 361,20 & 1071 & 651,27 \\
\hline 20 & 40 & $10 \pm 2$ & 2,5 & 0,54 & 62 & 195 & 361,20 & 1071 & 651,27 \\
\hline 40 & 20 & $10 \pm 2$ & 2,5 & 0,43 & 60 & 195 & 453 & 997,05 & 651,27 \\
\hline 40 & 40 & $10 \pm 2$ & 2,5 & 0,43 & 60 & 195 & 453 & 997,05 & 651,27 \\
\hline
\end{tabular}

\section{Hasil Uji Kuat tekan beton}

Pengujian kuat tekan beton dilakukan setelah benda uji beton mencapai umur 7 (tujuh) hari, 14 (empat belas) hari dan pada umur 28 (dua puluh delapan) hari. Dari hasil pengujian seperti pada tabel di bawah ini: 
Tabel 6.Tabel hasil kuat tekan beton

\begin{tabular}{|c|c|c|c|c|c|c|c|}
\hline \multirow{3}{*}{ No } & \multirow{3}{*}{$\begin{array}{c}\text { Mutu } \\
\text { beton }\end{array}$} & \multicolumn{6}{|c|}{ Kuat Tekan Rata-Rata Beton $\left(\mathrm{Kg} / \mathrm{cm}^{2}\right)$} \\
\hline & & \multicolumn{2}{|c|}{7 hari } & \multicolumn{2}{|c|}{14 hari } & \multicolumn{2}{|c|}{28 hari } \\
\hline & & D20mm & D40mm & D20mm & D40mm & D20mm & D40mm \\
\hline 1 & 20 & 149,15 & 163,18 & 178,10 & 175,47 & 201,79 & 212,31 \\
\hline \multicolumn{6}{|c|}{ Selisih pada umur 28 hari } & \multicolumn{2}{|c|}{$(\mathbf{5 , 0 \%})$} \\
\hline 2 & 40 & 181,61 & 183,36 & 305,31 & 308.82 & 386,90 & $\mathbf{3 9 8 , 3 0}$ \\
\hline \multicolumn{6}{|c|}{ Selisih pada umur 28 hari } & \multicolumn{2}{|c|}{$(2,9 \%)$} \\
\hline
\end{tabular}

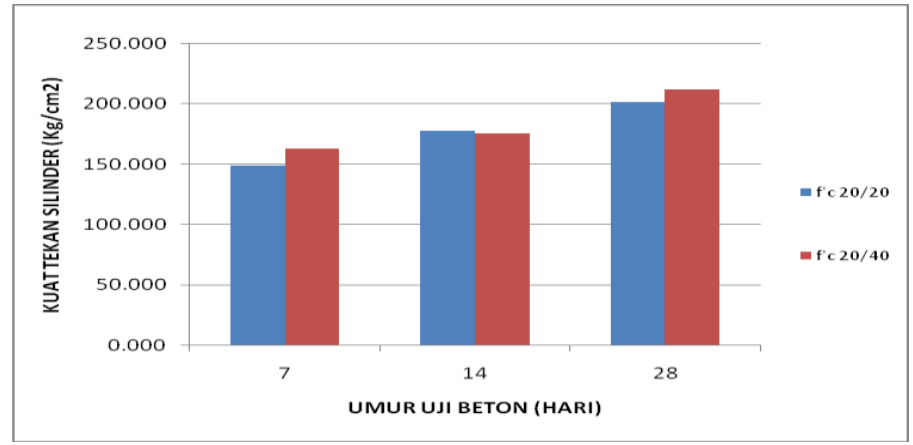

Gambar 5 Grafik perbandingan hasil tes kuat tekan beton f'c 20 MPa dengan agregat kasar berdiameter $20 \mathrm{~mm}$ dan $40 \mathrm{~mm}$

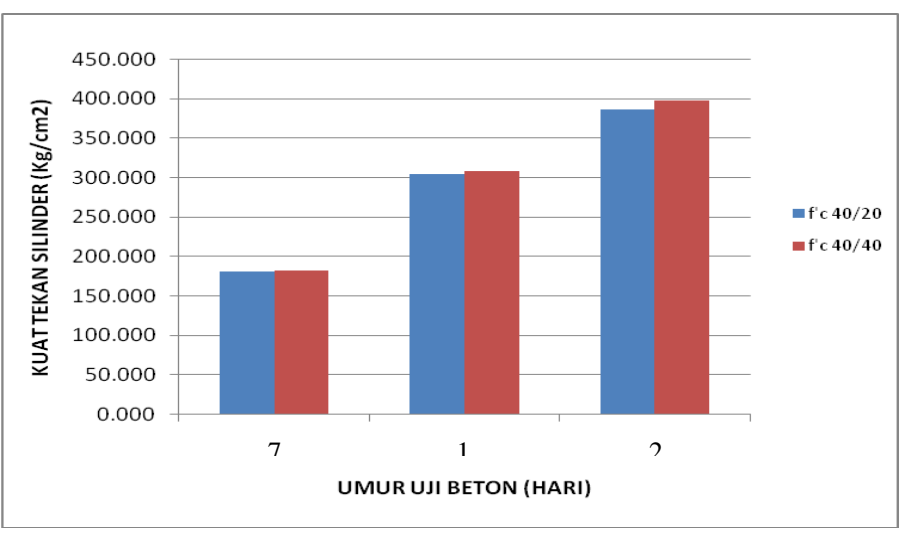

Gambar 6 Grafik perbandingan hasil tes kuat tekan beton f'c 40 MPa dengan agregat kasar berdiameter $20 \mathrm{~mm}$ dan $40 \mathrm{~mm}$

Dari tabel 6 dan grafik 5 dan 6 di atas dapat diketahui bahwa beton dengan menggunakan agregat berukuran diameter $40 \mathrm{~mm}$ lebih besar kuat tekannya pada umur 7 (tujuh) hari, 14 (empat belas) hari dan 28 (dua puluh delapan) hari daripada beton yang menggunakan agregat berukuran diameter $20 \mathrm{~mm}$.

Pada grafik terlihat untuk umur beton 28 (dua puluh delapan) hari, mutu beton f'c $20 \mathrm{MPa}$ dengan agregat berukuran $40 \mathrm{~mm}$ memeliki kuat tekan $10,52 \mathrm{Kg} / \mathrm{cm}^{2}$ lebih besar daripada beton dengan agregat ukuran $20 \mathrm{~mm}$. Kemudian untuk mutu beton f'c $40 \mathrm{MPa}$ dengan agregat berukuran $40 \mathrm{~mm}$ memeliki kuat tekan $11,46 \mathrm{Kg} / \mathrm{cm}^{2}$ lebih besar daripada beton dengan agregat berukuran $20 \mathrm{~mm}$. 
Standar Nasional Indonesia telah memberikan langkah-langkah untuk melakukan evaluasi beton keras dengan memperhatikan hasil uji kekuatan tekan silinder beton. Dalam konsep tata cara perancangan dan pelaksanaan konstruksi beton -1989 5.6.2.3 atau dalam Pedoman Beton 1989 pasal 4.7 tercantum bahwa pelaksanaan beton dapat diterima jika hasil kekuatan beton memenuhi dua syarat yang ditentukan yaitu: (1). Nilai rata-rata dari semua pasangan hasil uji (terdiri dari empat pasangan benda uji) tidak kurang dari $\left(\mathrm{f}^{\prime} \mathrm{c}+0,82 \mathrm{~S}\right)$ dengan $\mathrm{S}$ adalah standar deviasi. (2). Tidak satupun dari benda uji yang nilainya kurang dari $0,85 \mathrm{f}^{\prime} \mathrm{c}$.

Menurut PBI 71, bahwa beton tanpa menggunakan aditif, prosentase pencapaian kuat tekan untuk tiap tiap umurnya adalah sebagai berikut:

a. Beton dengan umur 7 (tujuh) hari pencapaian kuat tekannya adalah $65 \%$

b. Beton dengan umur 14 (empat belas) hari pencapaian kuat tekannya adalah $88 \%$

c. Beton dengan umur 28 (dua puluh delapan) hari pencapaian kuat tekannya adalah $100 \%$.

Dari keterangan di atas dapat ditabelkan sebagai berikut:

Tabel 7 Tabel hasil kuat tekan beton f'c $20 \mathrm{MPa}$

\begin{tabular}{rccccc}
\hline \multirow{2}{*}{$\begin{array}{c}\text { Mutu } \\
\text { beton }\end{array}$} & \multirow{2}{*}{ Umur (hari) } & \multicolumn{2}{c}{ f'c Ekp. } & \multirow{2}{*}{ f'c PBI 71 } & \multirow{2}{*}{ f'c SNI } \\
\cline { 2 - 4 } f'c 20 & & D20 & D40 & & \\
\cline { 2 - 4 } MPa & 7 & $\mathbf{1 4 9 . 4 5}$ & $\mathbf{1 6 3 , 1 8}$ & 130 & 110,5 \\
\cline { 2 - 5 } & 14 & $\mathbf{1 7 8 , 1 0}$ & $\mathbf{1 7 5 , 4 7}$ & 176 & 149,6 \\
\cline { 2 - 5 } & 28 & $\mathbf{2 0 1 , 7 9}$ & $\mathbf{2 1 2 , 3 1}$ & 200 & 170 \\
\hline
\end{tabular}

Tabel 8 Tabel hasil kuat tekan beton f'c $40 \mathrm{MPa}$

\begin{tabular}{|c|c|c|c|c|c|}
\hline \multirow{2}{*}{$\begin{array}{l}\text { Mutu } \\
\text { beton }\end{array}$} & \multirow{2}{*}{ Umur (hari) } & \multicolumn{2}{|c|}{$f^{\prime} c$ Ekp. } & \multirow{2}{*}{ f'c PBI 71} & \multirow{2}{*}{$\mathrm{f}^{\prime} \mathrm{c}$ SNI } \\
\hline & & D20 & D40 & & \\
\hline \multirow{3}{*}{$\begin{array}{l}\mathrm{f}^{\prime} \mathrm{c} 20 \\
\mathrm{MPa}\end{array}$} & 7 & 181,61 & 183,36 & 260 & 221 \\
\hline & 14 & $\mathbf{3 0 5 , 3 1}$ & 308.82 & 340 & 289 \\
\hline & 28 & 386,90 & 398,30 & 400 & 340 \\
\hline
\end{tabular}

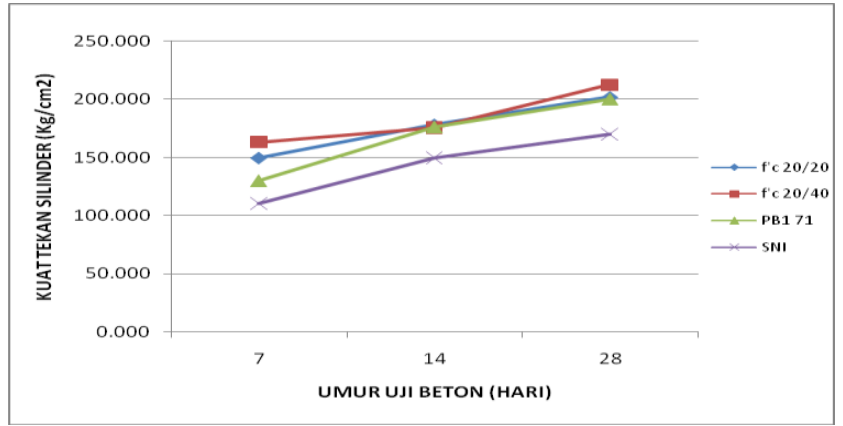

Gambar 7 Grafik perbandingan hasil tes kuat tekan beton f'c $20 \mathrm{MPa}$ antara eksperimen dengan PBI 71 dan SNI

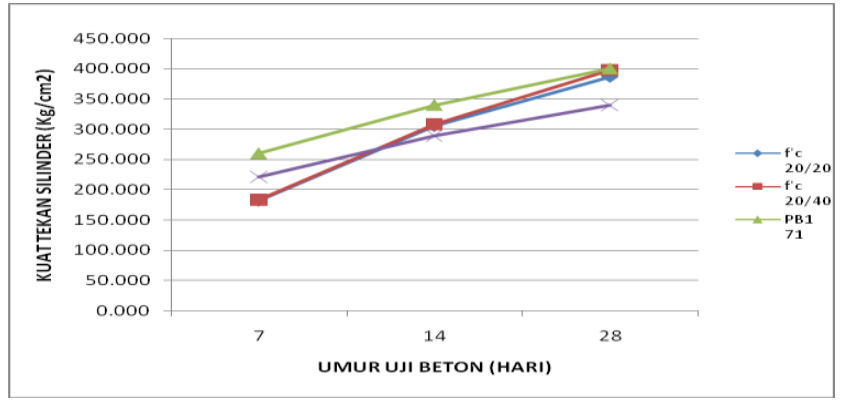

Gambar 8 Grafik perbandingan hasil tes kuat tekan beton f'c $40 \mathrm{MPa}$ antara PBI 71 dan SNI. 
Dari grafik di atas diketahui pencapaian kuat tekan antara eksperimen dengan standar PBI 71 dan SNI dan dari grafik diperoleh bahwa pada mutu f'c $20 \mathrm{MPa}$, kuat tekan eksperimen hampir sama dengan pencapaian PBI, sedangkan mutu f'c 40 Mpa hanya umur 28 (dua puluh delapan) hari yang sama dengan PBI71. Hal ini berarti bahwa uji kuat tekan beton f'c $20 \mathrm{MPa}$ dan f'c $40 \mathrm{MPa}$ masih sesuai dengan standar PBI 71.

\section{Hasil Uji Tarik Tak Langsung (Split cylinder test)}

pengujiaan kuat tarik dan tegangan belah beton dilakukan dengan benda uji slinder ukuran diameter $15 \mathrm{~cm}$ dan panjang $30 \mathrm{~cm}$ dengan hasil seperti tabel dan grafik di bawah ini:

Tabel 9 Kuat Tarik dan Tegangan Belah

\begin{tabular}{|c|c|c|c|c|}
\hline $\begin{array}{l}\text { Mutu Beton } \\
\text { (Mpa) }\end{array}$ & Fas & $\begin{array}{l}\text { Kuat tekan terhadap } \\
\text { tarik rata - rata } \\
\text { beton }(\mathrm{Kg})\end{array}$ & $\begin{array}{c}\text { Tegangan belah rata - rata } \\
\text { beton }\left(\mathrm{Kg} / \mathrm{cm}^{2}\right)\end{array}$ & $\begin{array}{c}\text { Selisih } \\
\text { perbandingan } \\
(\%)\end{array}$ \\
\hline f'c 20 D20 & \multirow{2}{*}{0,54} & 9,33 & 13,21 & \multirow{2}{*}{$(24 \%)$} \\
\hline$f^{\prime} \mathrm{c} 40 \mathrm{D} 40$ & & 12.33 & 17,40 & \\
\hline$f^{\prime} \mathrm{c} 40 \mathrm{D} 20$ & \multirow{2}{*}{0,43} & 11,00 & 15,56 & \multirow{2}{*}{$(23 \%)$} \\
\hline f'c 40 D40 & & 14,44 & 20,22 & \\
\hline
\end{tabular}

Dari hasil pengujian kuat tarik diperoleh bahwa untuk mutu beton f'c 20 maupun mutu beton f'c $40 \mathrm{MPa}$, nilai kuat tarik tertinggi dihasilkan oleh beton dengan menggunakan agregat kasar berdiameter $40 \mathrm{~mm}$ dengan selisi antara 4 sampai $5 \%$

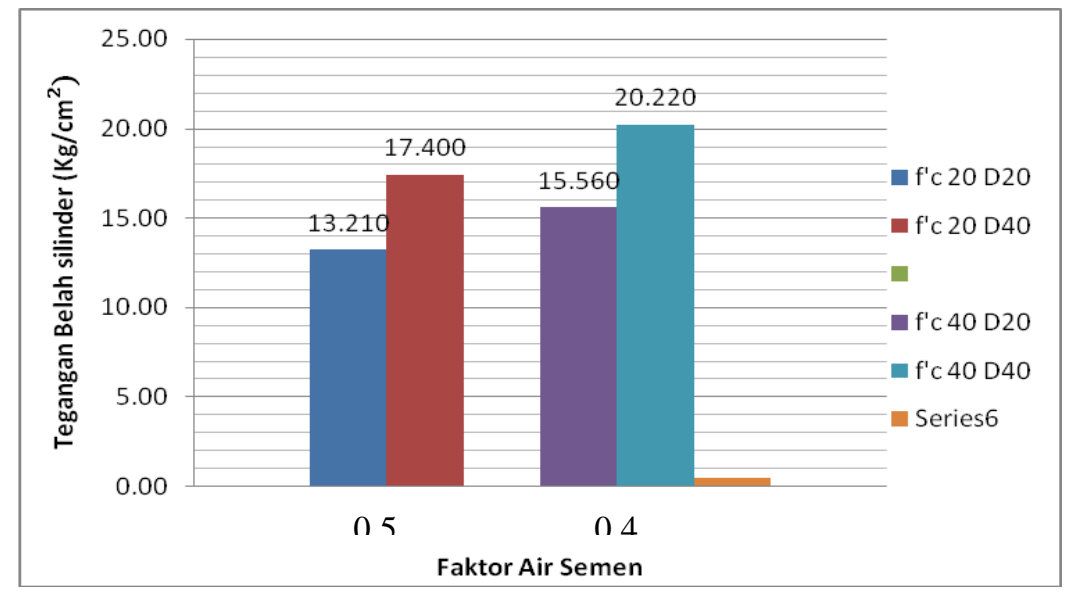

Gambar 9 Grafik perbandingan tegangan belah beton dengan faktor air semen

Pada beton dengan fas 0,54 tegangan belah tertinggi dihasilkan oleh beton dengan agregat kasar berdiameter 40 $\mathrm{mm}$ yaitu $17,4 \mathrm{Kg} / \mathrm{cm}^{2}$, sedangkan beton dengan fas 0,43 tegangan belah tertinggi dihasilkan oleh beton dengan agregat kasar berdiameter $40 \mathrm{~mm}$ yaitu $20,22 \mathrm{Kg} / \mathrm{cm}^{2}$

\section{Kuat Lentur Beton (Modulus of Rupture)}

Kuat lentur beton merupakan kemampuan beton didalam menahan momen. Nilai kuat lentur beton hasil penelitian dibandingkan dengan kuat lentur yang dipersyaratkan SNI 03-2846 (2002) pasal 11.5 yaitu sebesar $F_{r}=0,7 \sqrt{f^{\prime} c}$. Hasil kuat lentur beton disajikan pada Tabel 4.8 sebagai berikut : 
Tabel 10 Kuat Lentur perbandingan beton dengan agregat berdiameter $20 \mathrm{~mm}$ dan $40 \mathrm{~mm}$

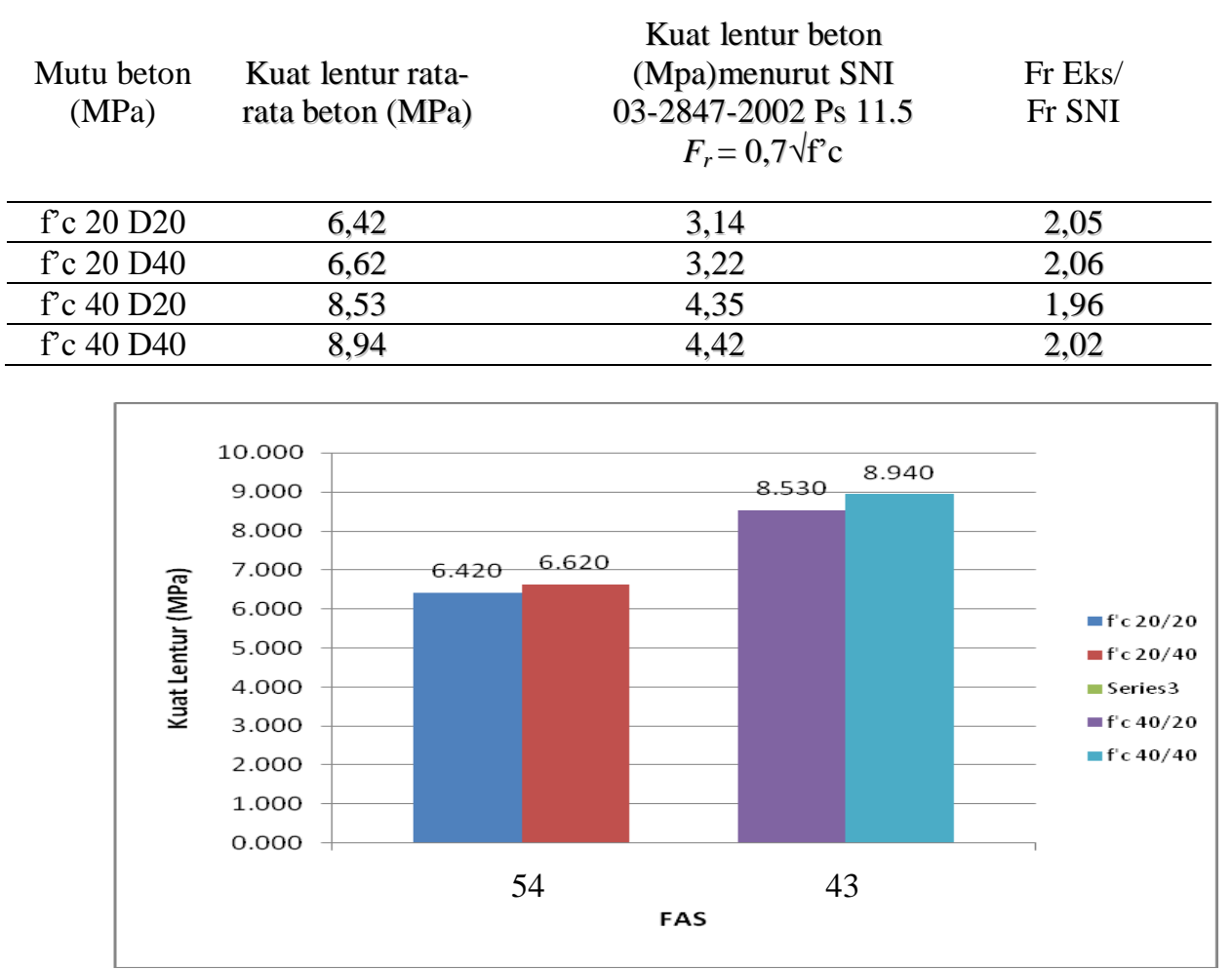

Gambar 10. Kuat lentur Beton Rata - Rata dengan Water Cement Ratio

Pada gambar 10 terlihat bahwa semakin semakin kuat tekan maka kuat lentur beton semakin tinggi. Besar kuat lentur untuk beton dengan agregat ukuran diameter $20 \mathrm{~mm}$ lebih kecil daripada ukuran diameter maksimal $40 \mathrm{~mm}$. Dari gambar 4.12 dapat disimpulkan kuat lentur beton hasil penelitian untuk semua komposisi lebih tinggi dibandingkan dengan kuat lentur menurut formasi yang ditetapkan SNI-03-2847 (2002) pasal 11.5 yaitu sebeasar $F_{r}=0,7 \sqrt{f^{\prime} c}$ (tabel IV.14).

\section{Hasil Tes Modulus Elastisitas}

Pengujian modulus elastisitas beton dilakukan dengan cara memberikan beben secara bertahap sampai mencapai beban $40 \%$ beban puncak. Benda uji $(\Delta \mathrm{L})$ untuk menghitung regangan longitudinal diperoleh dari hasil pembacaan pada gauge yang dipasang pada benda uji. Nilai modulus elastisitas beton hasil pengujian dibandingkan dengan modulus elastisitas yang dipersyaratkan SNI 03-2846(2002) pasal 10.5 yaitu sebesar $E_{c}=4700 \sqrt{f^{\prime} c}$.

Hasil penelitian dengan percobaan di Laboratorium diperoleh hasil modulus elastisitas beton disajikan pada tabel 11 berikut ini: 
Tabel 11. Modulus Elastisitas (E) perbandingan beton dengan agregat berdiameter $20 \mathrm{~mm}$ dan $40 \mathrm{~mm}$

\begin{tabular}{|c|c|c|c|c|}
\hline $\begin{array}{l}\text { Mutu beton } \\
\qquad(\mathrm{MPa})\end{array}$ & FAS & $\begin{array}{c}\text { Modulus Elastisitas } \\
\text { Rata-rata Beton } \\
\text { (Mpa) }\end{array}$ & $\begin{array}{l}\text { Modulus Elastisitas } \\
\text { Menurut SNI 03- } \\
\text { 2847-2002 Ps 10.5 }\end{array}$ & $\frac{E_{E X P}}{E_{S N I}}$ \\
\hline f'c 20 D20 & \multirow[t]{2}{*}{0,54} & 15200,8 & 21112,89 & 0,72 \\
\hline f'c 20 D40 & & 18777,3 & 21656,24 & 0,88 \\
\hline$f^{\prime} c 40$ D20 & \multirow[t]{2}{*}{0,43} & 26806 & 29234,60 & 0,91 \\
\hline f'c 40 D40 & & 22618,9 & 29662,18 & 0,76 \\
\hline
\end{tabular}

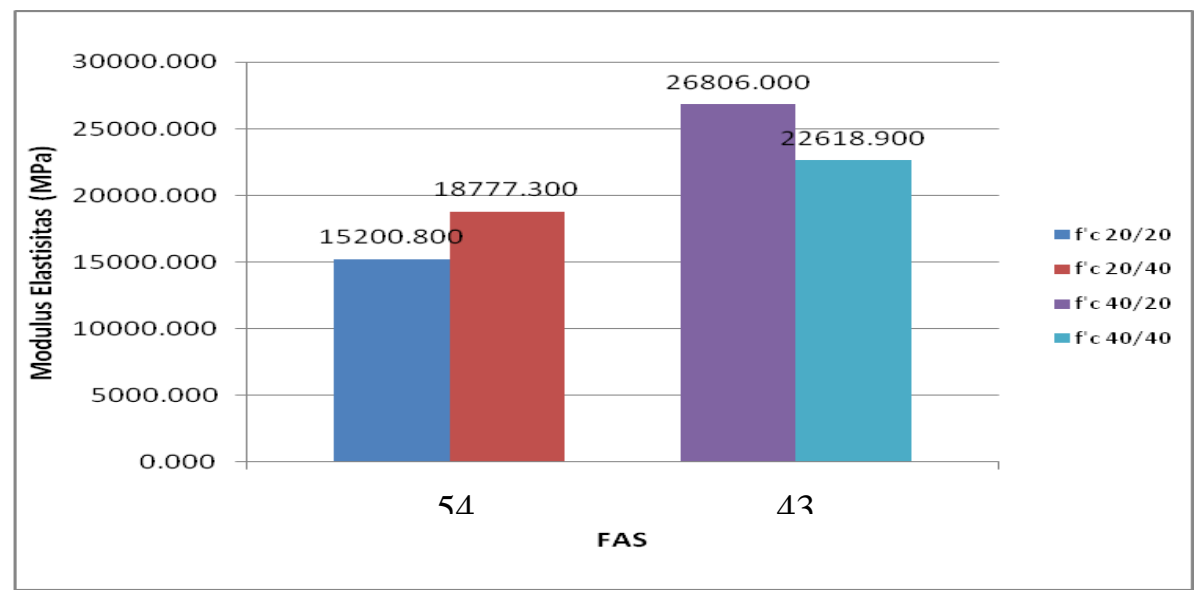

Gambar 11. Perbandingan Modulus Elastisitas Beton dengan agregat berdiameter 20 mm dan agregat dengan ukuran diameter $40 \mathrm{~mm}$

Dari gambar 11 ditunjukan bahwa semakin kecil nilai fas beton modulus elastisitas beton makin tinggi. Pada beton dengan fas 0,54 modulus elastisitas tertinggi dihasilkan oleh beton dengan agregat ukuran $20 \mathrm{~mm}$ yaitu 93495 $\mathrm{Kg} / \mathrm{cm}^{2}$, untuk beton dengan dengan fas 0,43 modulus elastisitas tertinggi dihasilkan oleh beton dengan ukuran agregat $40 \mathrm{~mm}$ yaitu $91682 \mathrm{Kg} / \mathrm{cm}^{2}$.

\section{KESIMPULAN DAN SARAN}

Berdasarkan hasil pembahasan hasil percobaan di Laboratorium seperti di atas, maka dapat diambil kesimpulan mengenai pengaruh ukuran diameter agregat kasar terhadap sifat-sifat beton mutu normal.

\section{Kesimpulan.}

a. Dengan proporsi mix yang sama, agregat berukuran diameter maksimal 40 menjadikan beton lebih besar kuat tekannya hingga 5\% daripada menggunakan agregat $20 \mathrm{~mm}$. Hal ini sesuai dengan hasil penelitian dari Simamora bahwa menggunakan agregat besar yang dicampur dengan agregat kecil dengan perbandingan optimum memiliki kuat tekan lebih besar daripada beton yang dominan menggunakan ukuran agregat kecil.

b. Sampel beton dengan diameter agregat $40 \mathrm{~mm}$ memiliki tegangan belah lebih besar $24 \%$ terhadap pembandingnya yaitu diameter agregat $20 \mathrm{~mm}$. Hal ini sesuai dengan kuat tekannya, semakin besar kuat tekan berarti kuat tarik juga semakin besar.

c. Kuat lentur dari percobaab beton dengan agregat besar $(40 \mathrm{~mm})$ lebih besar $5 \%$ daripada dengan agregat kecil (20 mm). 


\section{Saran}

Dalam percobaan ini disarankan kepada peneliti berikutnya sebagai berikut:

a. Perlu penelitian lebih lanjut, dengan variasi perbandingan ukuran split dan kuat tekan rencana yang lebih beragam, untuk mengetahui perilaku kekuatan tekan pada berbagai usia (variasi lanjutan).

b. Memperbanyak benda uji per variasi pada penelitian selanjutnya agar data yang didapat lebih akurat

\section{DAFTAR PUSTAKA:}

1. Antonius, (2011); Teknologi Bahan, Bahan Kuliah, Program Pasca Sarjana Magister Teknik Sipil, fakultas Teknik Unissula, Semarang.

2. Aprizon A, Pramudiyanto (2008); High Strength Concrete; www.pramudiyanto.wordpress.com

3. Civil Engineering Portal, http://www.engineeringcivil.com/, portal khusus untuk teknik sipil.

4. Mulyono, T., (2004); Teknologi Beton, Andi, Yogyakarta

5. F.X Supartono; Beton berkinerja tinggi, keunggulan dan permasalahannya; Jakarta : Seminar HAKI tanggal 25 Agustus 1998

6. Novica (1994); Pengaruh ukuran Maksimum Agregat dan Faktor Air Semen terhadap Sifat Mekanis Beton; Tesis Magister, ITB, 14 Oktober 1994.

7. Simamora (2008); Pengaruh komposisi agregat kasar beton terhadap kuat tekannya; Jurnal-2005

8. Syamsi Nur (2005); Pengaruh Perawatan terhadap Daya Tahan Beton; Jurnal Simetrika Vol.4 no.2 Agustus 2005: 317-322.

9. Triasmoko (2005); Studi Komparasi Mutu dan Biaya untuk Kolom Beton Mutu Normal sampai Mutu Tinggi; Tesis Magister, Unissula, September 2005.

10. Waddel. J.J,(1974) Concrete Construction Handbook, Mc Graw-Hill.

11. Wahyudi L., Rahim A.Syahril (1997); Struktur Beton Bertulang, Gramedia Pustaka Utama, Jakarta. 